Auranofin*

\title{
New oral gold compound for treatment of rheumatoid arthritis
}

\author{
A. E. FINKELSTEIN $\dagger$, D. T. WALZ, V. BATISTA, M. MIZRAJI, F. ROISMAN, AND
} A. MISHER

From the Smith Kline \& French Laboratories, Philadelphia, Pa., and the Institute of Clinical Pharmacology and Experimental Therapeutics, Buenos Aires, Argentina-Montevideo, Uruguay

\begin{abstract}
Finkelstein, A. E., Walz, D. T., Batista, V., Mizraji, M., Roisman, F., and Misher, A. (1976). Annals of the Rheumatic Diseases, 35, 251-257. Auranofin. New oral gold compound for treatment of rheumatoid arthritis. Eight patients with rheumatoid arthritis were treated with SK\&F D-39162 (auranofin), a new oral gold compound which was effective in suppressing adjuvant-induced arthritis in rats. Clinical and humoral parameters were studied during a 3-month period of drug administration followed by a 3-month period under placebo. The drug was absorbed, well tolerated, and its action was manifested by a drop in the mean IgG blood levels in the third week of treatment accompanied by clinical improvement after 5 weeks of oral gold intake. Together with IgG changes, an increase of the albumin ratio was observed, as well as a decrease of $\alpha_{2}$-globulin and rheumatoid factor titres. From a total number of 60 swollen joints found initially in the 8 patients only 17 were swollen at week 12 and 9 at week 15 . Although the number of patients treated was too small to allow definite conclusions, a follow-up study under placebo of clinical and laboratory changes in the same patients during another 3-month period showed that IgG serum levels rapidly reverted preceding a flare up of disease activity after withdrawal of the drug. This confirmed a direct role in cause-effect relation played by the new oral gold compound.
\end{abstract}

The Empire Rheumatism Council (1960), after a controlled study, confirmed the effectiveness of gold salts treatment for rheumatoid arthritis (RA). This was established, however, 30 years after Forestier's (1929) publication on gold therapy in chronic rheumatism. Furthermore, the Cooperating Clinics Committee of the American Rheumatism Association (1973), in a double-blind controlled study of gold salts therapy in 68 patients with clinical RA, confirmed the conclusions of the Empire Rheumatism Council with regard to the beneficial effects of gold treatment in RA.

Recently, Sigler and others (1974), in a 2-year double-blind study of the effects of gold salts in 27 RA patients, reported clinical improvement; and a radiological follow-up study showed that bone and cartilage destruction was arrested in several patients, the mean progression rate of destruction being significantly slowed for the gold-treated group. Gold compounds are, therefore, capable of successfully altering not only the clinical but also the radiological course of rheumatoid disease activity. The mechanism by which this is achieved is still unknown, and sequential studies of humoral changes during and after gold treatment are not available in the literature reviewed.

Recently, Sutton and others (1972) described a series of gold compounds in which the gold was complexed with trialkylphosphines, that exhibited antiarthritic activity after oral administration to adjuvant arthritic rats. SK \&F D-39162 (auranofin), one of the most active compounds in this series, was further evaluated by Walz and others $(1973,1976)$ in a variety of in vivo and in vitro test procedures and found to possess a unique pharmacological profile in 
that it inhibited antibody production, lysosomal enzyme release from phagocytosing leucocytes, and mediator release in immediate hypersensitivity reactions.

This report describes the use of SK\&F D-39162 in RA, its effect on disease activity, and a follow-up of sequential changes in humoral and clinical parameters which occurred during a 6-month period of evaluation: 3 months under oral gold compound treatment followed by 3 months on placebo.

\section{Materials and methods}

CLINICAL MATERIAL

Two groups of 4 patients each were studied, all having a clinical diagnosis of rheumatoid arthritis according to ARA criteria (Ropes and others, 1958). They were selected as being free from cardiovascular, renal, hepatic, and gastrointestinal diseases. None had been under immunosuppressive or gold treatment. Only one patient (Case 3) had previously received steroid therapy which was discontinued one month before gold was administered. Table I gives clinical and laboratory findings in the 8 RA patients. The stage and class of the patients follows Steinbrocker's criteria (Steinbrocker, Traeger, and Batterman, 1949).

ORAL GOLD ADMINISTRATION

Group I received SK\&F D-39162 orally in the form of $3 \mathrm{mg}$ capsules twice a day during 3 months; group II received $3 \mathrm{mg}$ twice a day during the first 3 weeks, followed by $3 \mathrm{mg}$ three times a day until completion of the 12-week treatment. Each capsule of $3 \mathrm{mg}$ of gold compound is equivalent to $0.87 \mathrm{mg}$ of gold. Therefore, group I received a total gold dose of $12.18 \mathrm{mg}$ weekly in daily oral doses; group II received the same quantity during the first 3 weeks followed by $0.87 \mathrm{mg}$ of gold three times a day, a total weekly intake of $18.27 \mathrm{mg}$ of gold. Placebo was given during the 3-month follow-up study. In no case did the patients know that the drug was discontinued after the first 3-month period. No patient withdrew from the study. 2 patients from group I (Cases 1 and 2) and 2 patients from group II (Cases 7 and 8 ) were hospitalized; the others were followed as outpatients. Hospitalized patients were seen by two physicians daily. Ambulatory patients were clinically controlled when they returned for laboratory determinations. The rheumatologist recorded symptoms and pertinent physical findings, with special attention to the morning stiffness period, and the number of swollen joints in each patient. Fasting blood specimens were drawn from each patient and urine samples were collected for the following laboratory studies: complete blood count (haemoglobin, haematocrit, white blood count, differential), platelets, ESR, urinalysis, blood urea nitrogen, creatinine, uric acid, total bilirubin, SGOT, SGPT, lactic dehydrogenase, alkaline phosphatase, serum glucose, $\mathrm{Na}, \mathrm{Cl}, \mathrm{K}, \mathrm{CO}_{2}$, creatinine clearance, and stools for occult blood. These studies were done at weeks $0,1,2,3,5.7,9$, and 12 , and continued in a similar sequence during the following 3 months on placebo. Blood and urine samples were taken twice weekly for gold determination by atomic absorption spectroscopy according to Lorber and others (1968). Serum protein electrophoresis was done on acetate cellulose gel and IgG, IgM, IgA determination by radial immunodiffusion (Mancini, Carbonara, and Heremans, 1965), using Hyland plates. Rheumatoid factor titres were determined according to Singer and Plotz (1956).

IN VIVO BINDING DISTRIBUTION STUDIES OF SK\&F D-39162 TO SERUM PROTEIN FRACTION IN RA

Preparative electrophoresis on cellogel block, $0.25 \times 6 \times 17$ $\mathrm{cm}$, were carried out with $0.5 \mathrm{ml}$ of serum (Case 7) at week

Table I Changes of clinical and laboratory parameters during and after treatment with SK\&F D-39162

\begin{tabular}{|c|c|c|c|c|c|c|c|c|c|c|c|}
\hline Case No. & Sex & $\begin{array}{l}\text { Age } \\
\text { (years) }\end{array}$ & $\begin{array}{l}\text { Duration } \\
\text { (years) }\end{array}$ & Week & $\begin{array}{l}\text { Stage,* } \\
\text { class }\end{array}$ & ESR & $R F \dagger$ & $\begin{array}{l}I g G \\
(g / l)\end{array}$ & $\begin{array}{l}\alpha_{2-} \\
\text { globulin } \\
(g / l)\end{array}$ & $\begin{array}{l}\text { Swollen } \\
\text { joints }\end{array}$ & $\begin{array}{l}\text { Morning } \\
\text { stiffness } \\
\text { (hours) }\end{array}$ \\
\hline \multirow{2}{*}{\multicolumn{12}{|c|}{$\underset{1}{G r o u p} I$}} \\
\hline & $\mathbf{F}$ & 35 & $6 \mathrm{~m}$ & $\begin{array}{r}1 \\
12\end{array}$ & $\begin{array}{l}\text { I, } 3 \\
\text { I, } 1\end{array}$ & $\begin{array}{r}100 \\
40\end{array}$ & $\begin{array}{r}160 \\
80\end{array}$ & $\begin{array}{l}17 \cdot 00 \\
11 \cdot 50\end{array}$ & $\begin{array}{r}13 \cdot 7 \\
7.6\end{array}$ & $\begin{array}{r}14 \\
8\end{array}$ & \\
\hline 2 & $\mathbf{F}$ & 49 & 8 & $\begin{array}{r}1 \\
12\end{array}$ & $\begin{array}{l}\text { III, } 3 \\
\text { III, } 2\end{array}$ & $\begin{array}{l}65 \\
38\end{array}$ & $\begin{array}{r}160 \\
80\end{array}$ & $\begin{array}{l}27.90 \\
14 \cdot 50\end{array}$ & $\begin{array}{l}9 \cdot 4 \\
4 \cdot 8\end{array}$ & $\begin{array}{l}2 \\
1\end{array}$ & $\begin{array}{l}4 \\
1 / 4\end{array}$ \\
\hline 3 & $\mathbf{M}$ & 55 & 2 & 12 & II, 2 & $\begin{array}{l}64 \\
38\end{array}$ & $\begin{array}{r}320 \\
40\end{array}$ & $\begin{array}{l}22.00 \\
15.00\end{array}$ & $\begin{array}{r}12.5 \\
8.2\end{array}$ & 8 & \\
\hline 4 & $\mathbf{F}$ & 48 & 30 & $\begin{array}{r}1 \\
12\end{array}$ & $\begin{array}{l}\text { IV, } 2 \\
\text { IV, } 2\end{array}$ & $\begin{array}{l}32 \\
27\end{array}$ & $\begin{array}{r}160 \\
40\end{array}$ & $\begin{array}{l}18 \cdot 50 \\
13 \cdot 80\end{array}$ & $\begin{array}{l}7.2 \\
6.9\end{array}$ & $\begin{array}{l}3 \\
1\end{array}$ & $\begin{array}{l}1 / 2 \\
0\end{array}$ \\
\hline \multicolumn{12}{|l|}{ Group II } \\
\hline 5 & $\mathbf{M}$ & 64 & 3 & $\begin{array}{r}1 \\
12\end{array}$ & $\begin{array}{l}\text { III, } 3 \\
\text { III, } 2\end{array}$ & $\begin{array}{l}60 \\
39\end{array}$ & $\begin{array}{r}640 \\
80\end{array}$ & $\begin{array}{l}18 \cdot 40 \\
12 \cdot 80\end{array}$ & $\begin{array}{l}12.6 \\
10.3\end{array}$ & $\begin{array}{r}10 \\
0\end{array}$ & $\begin{array}{l}1 \\
0\end{array}$ \\
\hline 6 & $\mathbf{F}$ & 43 & $8 \mathrm{~m}$ & $\begin{array}{r}1 \\
12\end{array}$ & I, 3 & 30 & 80 & $\begin{array}{l}22 \cdot 40 \\
12.80\end{array}$ & $7 \cdot 7$ & 17 & 3 \\
\hline 7 & $\mathbf{F}$ & 62 & 16 & 1 & IV, 4 & 55 & 40 & $17 \cdot 40$ & $\begin{array}{l}4.2 \\
9.2 \\
0.2\end{array}$ & 4 & 3 \\
\hline 8 & $\mathbf{F}$ & 55 & 7 & $\begin{array}{r}12 \\
12\end{array}$ & $\begin{array}{l}\text { IV, } 4 \\
\text { IV, } 3\end{array}$ & $\begin{array}{l}48 \\
40 \\
35\end{array}$ & $\begin{array}{l}20 \\
80 \\
40\end{array}$ & $\begin{array}{l}12.80 \\
12.80\end{array}$ & $\begin{array}{r}8.3 \\
11 \cdot 2 \\
8.4\end{array}$ & $\begin{array}{l}3 \\
2 \\
1\end{array}$ & $\begin{array}{l}1 \\
2 \\
2\end{array}$ \\
\hline
\end{tabular}

Total number of swollen joints: week $1: 60$, week $12: 17$. 
12 under oral SK\&F D-39162 treatment. $140 \mathrm{~V}$ were applied during a 4-hour running period, using a TRISbarbital buffer $(10.30 \mathrm{~g}$ sodium diethylbarbiturate; $1.84 \mathrm{~g}$ diethylbarbituric acid; and $7.2 \mathrm{~g}$ TRIS in 1.01 distilled water). Serum fraction positions were determined and impressed on a cellodry film, then the fractions were cut with a razor blade and eluted. Protein determinations of the eluted fractions were performed according to Lowry's method (Lowry and others, 1951) and gold levels of each fraction were estimated by neutron activation analysis.

\section{Results}

BLOOD AND URINE GOLD LEVELS

The oral gold compound was well absorbed by the 8 patients during the first 3 months of treatment. Fig. 1 shows curves obtained with the mean blood gold levels of groups I and II. In the third week, when group II increased the oral gold intake to $3 \mathrm{mg}$ t.i.d., a rise of blood gold concentration took place. There is no evidence of a 'steady state' or 'plateau' in either group. A straight line of increased blood gold levels in function of time is clearly shown.

Similar ascendant curves were obtained with the mean values of 24-hour urinary gold excretion in function of time in both groups of RA patients. The correlation of mean values of blood gold levels with mean values of 24-hour urinary gold excretion in both groups of patients is shown in Fig. 2. The correlation between blood and urine gold levels was studied by the least square statistical method, and the patients in group I showed a correlation coefficient of 0.8663 (highly significant, $P<0.001$ ) and a regression coefficient of $0.37 \mu \mathrm{g} / \mathrm{ml}$ per each $100 \mu \mathrm{g} / 24 \mathrm{~h}$ urinary gold excreted. Group II showed similar results: correlation coefficient 0.7972 (highly significant, $P<0.001$ ), and a regression coefficient of $0.36 \mu \mathrm{g} / \mathrm{ml}$ per each $100 \mu \mathrm{g}$ of gold excreted in urine.

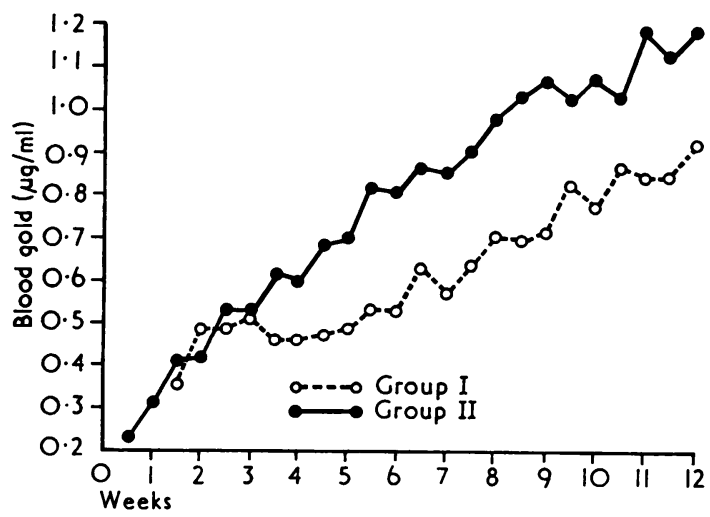

FIG. 1 Effect of daily oral administration of $S K \& F$ D-39162 on blood gold levels in RA patients. Group I received $3 \mathrm{mg}$ twice a day during 3 months. Group II received $3 \mathrm{mg}$ twice a day during the first 3 weeks, followed by $3 \mathrm{mg}$ three times a day until completion of the 12-week treatment

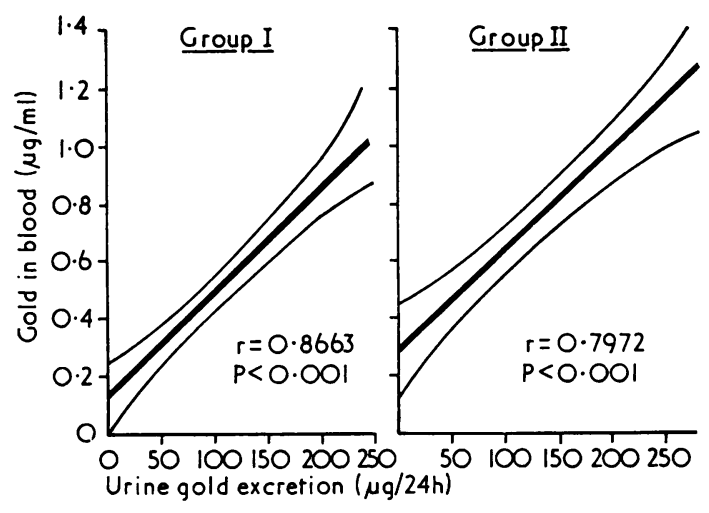

FIG. 2 Correlation of blood gold levels and 24-hour urinary gold excretion in RA patients (groups $I$ and II) treated with SK\&F D-39162. Regression line is heavy diagonal line; $95 \%$ confidence limits are represented by thin diagonal lines

SERUM PROTEIN BINDING DISTRIBUTION

In vivo studies of gold binding distribution to serum protein fractions at week 12 on oral SK\&F D-39162 was done by neutron activation analysis of cellogel block eluted proteins (see Methods). $81.8 \%$ of gold binds to albumin; $4.8 \%$ to $\alpha_{1}$-globulin; $6.9 \%$ to $\alpha_{2}$-globulin; and $6.5 \%$ to $\beta$ and $\gamma$ globulins. The blood gold level at week 12 reached $1.5 \mu \mathrm{g} / \mathrm{ml}$ as determined by absorption atomic spectroscopy.

\section{LABORATORY AND CLINICAL CHANGES}

Routine laboratory studies showed no abnormality attributable to the gold compound in the 8 patients, with the exception of Case 2 in whom the alkaline phosphatase and SGOT started to rise in the first week. In the same patient the white cell count was in the lower limit of normal at the third week. At the ninth week the enzyme values started to normalize in spite of the patient being on the drug again after 20 days' interruption of treatment. It is difficult to be sure of a cause-effect relation since $26 \%$ of the rheumatoid arthritis population have been reported to have high alkaline phosphatase and SGOT values (Webb and others, 1975).

No rash or gastrointestinal disorders were reported in the 8 patients. There were no clinically significant changes in blood pressure, pulse, electrocardiogram, and ophthalmological studies were normal. No changes in body weight took place.

Clinical improvement was manifested by a decrease in the duration of morning stiffness and in the total number of swollen joints after 3 months of oral gold administration. Table I compares these objective clinical changes with changes in laboratory parameters during this period. It can be seen that after 12 weeks on gold therapy only 17 joints were objectively swollen out of the total of 60 swollen 
joints before treatment in the 8 patients. This objective evidence of decreased rheumatoid disease activity was paralleled significantly by serum protein and immunoglobulin changes.

\section{SERUM PROTEIN AND IMMUNOGLOBULIN STUDIES}

The most significant and consistent changes were observed at follow-up in the variation of the serum protein levels which occurred during and after total oral gold administration. A marked increase of serum albumin and decrease of $\alpha_{2}$ - and $\gamma$-globulin was a constant finding in the patients studied. The mean serum albumin concentration of the 8 patients before treatment was $26.7 \mathrm{~g} / \mathrm{l}(2.67 \mathrm{~g} / 100 \mathrm{ml})$. At the end of 3 months' treatment the mean value increased to $32.6 \mathrm{~g} / 1(3.26 \mathrm{~g} / 100 \mathrm{ml})$, and at the end of the following 3 months' treatment on placebo the mean serum albumin concentration was $36.6 \mathrm{~g} / 1 \quad(3.66$ $\mathrm{g} / 100 \mathrm{ml}$ ). Table II gives the albumin-globulin ratio values before, during, and after treatment in patients of both groups. While the increase in albumin and decrease of $\alpha_{2}$-globulin remains stable even at the third month on placebo (Fig. 3), after gold was stopped the $\gamma$-globulin blood levels, which decreased during treatment by $26.5 \%$ at week 12 , returned to

Table II Albumin-globulin ratio changes before, during, and after treatment with SK\&F D-39162

\begin{tabular}{|c|c|c|c|c|c|c|}
\hline \multicolumn{7}{|c|}{ Group I } \\
\hline & 0 & 0.53 & $0 \cdot 44$ & 0.59 & 0.66 & 0.55 \\
\hline & $\begin{array}{r}1 \\
2 \\
3 \\
5 \\
7 \\
9 \\
12\end{array}$ & $\begin{array}{l}0.55 \\
0.57 \\
0.56 \\
0.78 \\
0.78 \\
0.83 \\
0.75\end{array}$ & $\begin{array}{l}0.38 \\
0.55 \\
0.61 \\
0.74 \\
0.80 \\
0.82 \\
0.99\end{array}$ & $\begin{array}{l}0.54 \\
0.64 \\
0.71 \\
0.82 \\
0.86 \\
0.77 \\
0.88\end{array}$ & $\begin{array}{l}0.72 \\
0.82 \\
0.93 \\
0.86 \\
1.15 \\
1.07 \\
0.92\end{array}$ & $\begin{array}{l}0.55 \\
0.64 \\
0.70 \\
0.80 \\
0.90 \\
0.87 \\
0.88\end{array}$ \\
\hline & $\begin{array}{l}15 \\
17 \\
19 \\
24\end{array}$ & $\begin{array}{l}0.84 \\
0.83 \\
1.12 \\
0.93\end{array}$ & $\begin{array}{l}0.55 \\
0.82 \\
0.84 \\
0.68\end{array}$ & $\begin{array}{l}0.81 \\
1 \cdot 14 \\
0.96 \\
0.84\end{array}$ & $\begin{array}{l}1.15 \\
1.06 \\
0.89 \\
0.99\end{array}$ & $\begin{array}{l}0.84 \\
0.96 \\
0.95 \\
0.86\end{array}$ \\
\hline \multicolumn{6}{|c|}{ Group II } & Mean \\
\hline & 0 & 0.69 & 0.60 & 0.58 & 0.68 & 0.64 \\
\hline 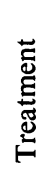 & $\begin{array}{r}1 \\
2 \\
3 \\
5 \\
7 \\
9 \\
12\end{array}$ & $\begin{array}{l}0.64 \\
0.73 \\
0.97 \\
0.91 \\
0.74 \\
0.88 \\
0.98\end{array}$ & $\begin{array}{l}0.82 \\
0.88 \\
0.96 \\
0.87 \\
0.93 \\
0.80 \\
1.09\end{array}$ & $\begin{array}{l}0.75 \\
0.80 \\
0.77 \\
0.84 \\
0.92 \\
0.89 \\
0.91\end{array}$ & $\begin{array}{l}0.78 \\
0.93 \\
1.11 \\
0.97 \\
0.92 \\
0.96 \\
0.99\end{array}$ & $\begin{array}{l}0.75 \\
0.83 \\
0.95 \\
0.90 \\
0.88 \\
0.88 \\
0.99\end{array}$ \\
\hline & $\begin{array}{l}15 \\
17\end{array}$ & $\begin{array}{l}0.98 \\
1.04\end{array}$ & $\begin{array}{l}0.93 \\
1.01\end{array}$ & $\begin{array}{l}0.88 \\
0.97\end{array}$ & $\begin{array}{l}0.88 \\
0.87\end{array}$ & $\begin{array}{l}0.92 \\
0.97\end{array}$ \\
\hline
\end{tabular}

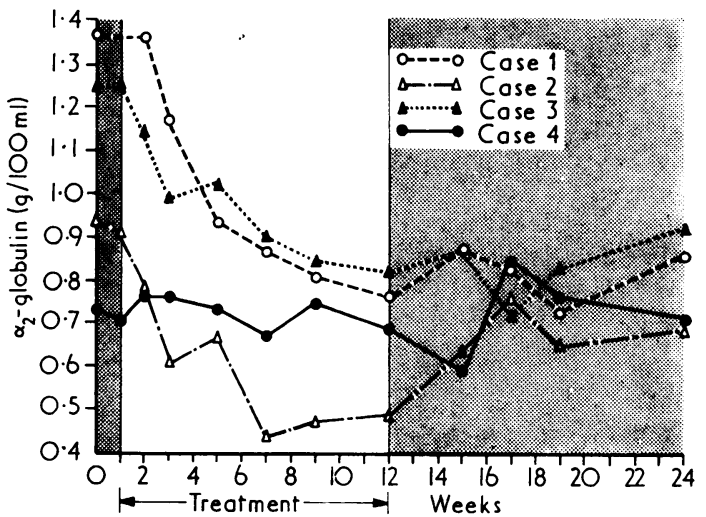

FIG.3 $\alpha_{2}$-Globulin values in four RA patients (group I) before, during, and after treatment with $S K \& F$ D-39162, which was administered orally at a dose of $3 \mathrm{mg}$ twice a day. Conversion: Traditional to SI Units- $\alpha_{2}$-globulin: $1 \mathrm{~g} / 100$ $\mathrm{ml} \approx 10 \mathrm{~g} / \mathrm{l}$

the pre-gold values at the end of the 6-month study (Fig. 4).

Statistical analysis of variance of polynomial regression of $\alpha_{2}$-globulin and IgG was highly significant $(P<0.005)$. Studies between the relation of dailyo gold intake and decrease in IgG, according to oure data, showed that daily oral administration of $6 \mathrm{mg}$ of the gold compound $(1.7 \mathrm{mg}$ of gold) produces a decrease of $1.24 \mathrm{~g} / 1(123.5 \mathrm{mg} / 100 \mathrm{ml})$ of $\mathrm{IgG}$ per week during the first 9 weeks of treatment.

In Table III it can be seen that from the total $\gamma$-globulin values, IgG has the most sensitive response to the gold compound. Similar results were obtained with the patients of group II. Rheumatoid factor titres dropped in all of the patients treated (Table I),

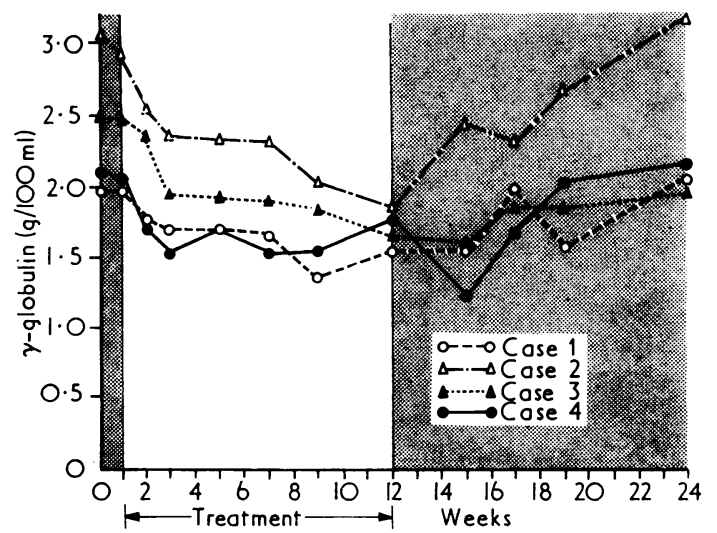

FIG. $4 \gamma$-Globulin values in four RA patients (group I) before, during, and after treatment with $S K \& F D-39162$, which was administered orally at a dose of $3 \mathrm{mg}$ twice a day. Conversion: Traditional to SI Units-y-globulin: $1 \mathrm{~g} / 100$ $\mathrm{ml} \approx 10 \mathrm{~g} / \mathrm{l}$ 
Table III Serum IgG, IgA, IgM levels ( $g / l)$ before, during, and after treatment with SK\&F D-39162

\begin{tabular}{|c|c|c|c|c|c|c|c|c|c|c|c|c|}
\hline \multirow[t]{2}{*}{$\underset{\text { Week }}{\text { Group I }}$} & \multicolumn{3}{|c|}{ Case 1} & \multicolumn{3}{|c|}{ Case 2} & \multicolumn{3}{|c|}{ Case 3} & \multicolumn{3}{|c|}{ Case 4} \\
\hline & IgG & IgA & IgM & IgG & IgA & IgM & IgG & $\operatorname{Ig} A$ & IgM & IgG & IgA & IgM \\
\hline 0 & $17 \cdot 0$ & $2 \cdot 45$ & $1 \cdot 4$ & $27 \cdot 9$ & $1 \cdot 3$ & $1 \cdot 4$ & $22 \cdot 0$ & $3 \cdot 4$ & 0.8 & $18 \cdot 5$ & $2 \cdot 8$ & $1 \cdot 1$ \\
\hline 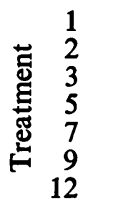 & $\begin{array}{l}16 \cdot 0 \\
17 \cdot 0 \\
14 \cdot 0 \\
14 \cdot 8 \\
14 \cdot 8 \\
12 \cdot 1 \\
11 \cdot 5\end{array}$ & $\begin{array}{l}1 \cdot 88 \\
1 \cdot 28 \\
2 \cdot 1 \\
1 \cdot 85 \\
1 \cdot 15 \\
2 \cdot 2 \\
1 \cdot 5\end{array}$ & $\begin{array}{l}1 \cdot 4 \\
1 \cdot 1 \\
1 \cdot 1 \\
1 \cdot 17 \\
1.04 \\
1 \cdot 3 \\
1 \cdot 8\end{array}$ & $\begin{array}{l}27 \cdot 0 \\
23 \cdot 2 \\
20 \cdot 2 \\
18 \cdot 0 \\
20 \cdot 4 \\
17 \cdot 1 \\
14 \cdot 5\end{array}$ & $\begin{array}{l}1 \cdot 1 \\
1 \cdot 45 \\
1 \cdot 48 \\
1 \cdot 3 \\
1 \cdot 48 \\
1 \cdot 4 \\
1 \cdot 15\end{array}$ & $\begin{array}{l}1.4 \\
1.86 \\
1 \cdot 33 \\
1 \cdot 16 \\
2.42 \\
1.68 \\
2 \cdot 14\end{array}$ & $\begin{array}{l}22 \cdot 0 \\
20 \cdot 2 \\
17 \cdot 0 \\
14 \cdot 9 \\
17 \cdot 5 \\
17 \cdot 3 \\
15 \cdot 0\end{array}$ & $\begin{array}{l}3 \cdot 36 \\
3 \cdot 36 \\
3 \cdot 1 \\
3 \cdot 6 \\
3 \cdot 4 \\
3 \cdot 4 \\
3 \cdot 1\end{array}$ & $\begin{array}{l}0.8 \\
0.78 \\
1.08 \\
0.9 \\
0 \cdot 99 \\
1 \cdot 1 \\
1 \cdot 1\end{array}$ & $\begin{array}{l}18 \cdot 2 \\
15 \cdot 8 \\
14 \cdot 0 \\
13 \cdot 5 \\
14.9 \\
14 \cdot 1 \\
13 \cdot 8\end{array}$ & $\begin{array}{l}2.9 \\
2.8 \\
3.0 \\
2.8 \\
2.8 \\
2.6 \\
2.2\end{array}$ & $\begin{array}{l}1 \cdot 1 \\
0.98 \\
1.36 \\
1 \cdot 14 \\
1.4 \\
1.0 \\
1.03\end{array}$ \\
\hline $\begin{array}{l}15 \\
17 \\
19 \\
24\end{array}$ & $\begin{array}{l}12 \cdot 9 \\
17 \cdot 0 \\
14 \cdot 1 \\
15 \cdot 6\end{array}$ & $\begin{array}{l}1 \cdot 3 \\
1 \cdot 5 \\
1 \cdot 76 \\
2 \cdot 0\end{array}$ & $\begin{array}{l}1 \cdot 1 \\
1 \cdot 84 \\
1 \cdot 1 \\
3 \cdot 0\end{array}$ & $\begin{array}{l}18 \cdot 2 \\
18 \cdot 4 \\
23 \cdot 0 \\
26 \cdot 8\end{array}$ & $\begin{array}{l}1 \cdot 3 \\
1.6 \\
1.45 \\
1.36\end{array}$ & $\begin{array}{l}1.34 \\
2.48 \\
1.86 \\
3.0\end{array}$ & $\begin{array}{l}14.6 \\
16.0 \\
16.5 \\
17.6\end{array}$ & $\begin{array}{l}3 \cdot 0 \\
3 \cdot 1 \\
3 \cdot 0 \\
3 \cdot 1\end{array}$ & $\begin{array}{l}0.9 \\
1.0 \\
1 \cdot 3 \\
1 \cdot 1\end{array}$ & $\begin{array}{l}14 \cdot 2 \\
14 \cdot 6 \\
16 \cdot 5 \\
16.8\end{array}$ & $\begin{array}{l}2.6 \\
2.9 \\
3.7 \\
3.0\end{array}$ & $\begin{array}{l}0.94 \\
1.6 \\
1.72 \\
1.9\end{array}$ \\
\hline
\end{tabular}

and the greater clinical and laboratory responsiveness was observed at the earliest stage of disease.

\section{Discussion}

SK\&F D-39162 was well tolerated and absorbed through the gastrointestinal tract in the 8 RA patients in whom the gold levels were studied. The blood gold levels reached with daily doses of SK\&F D-39162 were one-half or one-third lower than the blood gold levels reached by the classical treatment with parenteral gold. In patients treated with SK\&F D-39162 the serum gold concentrations failed to correlate with the clinical course of the disease in the patients studied. Gottlieb, Smith, and Smith (1974) and Gerber and others (1972) also could not find such a correlation after chrysotherapy.

Contrary to the lack of correlation between serum blood gold levels and the 24-hour urinary gold secretion reported during parenteral gold administration (Lorber and others, 1973), in this report on oral chrysotherapy there is a greater blood gold level stability, and a direct correlation is observed between the mean values of blood gold levels and 24-hour urinary gold excretion.

Although a limited group of patients have been studied, the four stages of RA were represented, and the greatest responsiveness to the oral gold was achieved during the earliest stages of the disease. Before treatment all the patients presented the classical humoral picture of active rheumatoid arthritis, as evidenced by low albumin, high $\alpha_{2}-$ globulin, and high total $\gamma$-globulin values. This electrophoretic profile started to normalize at the third week of treatment with the compound. Clinical improvement, shown by decreased duration of morning stiffness and number of swollen joints, began the fifth week of treatment.
All our rheumatoid patients presented hypoalbuminaemia (mean value $26 \mathrm{~g} / 1(2.6 \mathrm{~g} / 100 \mathrm{ml}$ ) before oral gold). The striking result after oral gold was a stable increase of $10 \mathrm{~g} / 1(1 \mathrm{~g} / 100 \mathrm{ml})$ average value for 8 patients, lasting even 3 months after gold was discontinued. Studies of albumin metabolism in RA (Wilkinson and others, 1965; and Ballantyne, Fleck, and Dick, 1971) showed that the intravascular, extravascular, and total body albumin contents were significantly lower than normals, and values for fractional catabolic rates were increased and did correlate with disease activity. The mechanism by which SK\&F D-39162 protects the enhanced degradation of albumin in RA requires further investigation. It is important to point out that $81.8 \%$ of gold binds in vivo with the albumin fraction according to our studies with SK\&F D-39162 as determined by neutron activation analysis. Mascarenhas, Granda, and Freyberg (1972), using ${ }^{195} \mathrm{AuCl}$ after exchange with gold sodium thiomalate in in vitro studies, reported that $95 \%$ of the radioactivity was associated with the albumin fraction. Further studies are necessary to confirm the existence of a higher binding affinity to the serum globulin fractions of the oral gold.

It was found at follow-up that during the 3-month placebo period after gold was stopped, when each patient became his own control, some insight was gained into role played by the compound at an immunological level. The IgG reverted on placebo (Fig. 4), after a highly significant drop $(P<0.005)$, to its pretreatment levels. Clinically, this was paralleled when a flare-up of disease followed the IgG reversion to the higher pre-gold levels at the third month on placebo.

Therefore, the circulating immune response is modified by the administration of SK\&F D-39162, as evidenced by its effect upon the changes produced 
on the serum IgG levels, and a drop of the initial rheumatoid factor titres. Serum IgG concentration in the 8 patients studied with SK\&F D-39162 were above normal values at the beginning of oral gold administration. Statistical analysis of the relation of daily gold intake and IgG serum level variation showed that a daily oral intake of $1.7 \mathrm{mg}$ of gold produced a decrease of $1.24 \mathrm{~g} / 1(123.5 \mathrm{mg} / 100 \mathrm{ml})$ of IgG serum concentration per week during the first nine weeks of treatment.

During the last decade it has become evident that RA is a good example of a generalized immune complex disease, in which vasculitis and tissue deposition of immunocomplexes play an important role in the rheumatoid inflammation (Carter, 1973). In the light of the accumulation of evidence suggesting the role that IgG-RF might play through the circulating immunocomplexes or their tissue deposition in rheumatoid disease (Finkelstein and others, 1961; Kunkel and others, 1961; Chodirker and Tomasi, 1963; Schrohenloher, 1966; Munthe and Natvig, 1971; Gordon and others, 1975), the effect of SK\&F D-39162 upon IgG might be its most important property as an antiarthritic agent. Furthermore, based on this action, the oral gold compound might also have its place in the treatment of the hyper- viscosity syndrome described in rheumatoid arthritis due to intermediate complexes formed by self association of IgG-RFs (Pope and others, 1975), and in other disorders associated with hypergammaglobulinaemia.

Finally, it is not known whether the improvement of SK\&F D-39162 on the immunological parameters in RA is produced through the inhibition of immunoglobulin synthesis or to an effect of this new compound upon the triggering aetiological factor of the disease. In favour of this last possibility is the lowering effect that this drug exercises upon such a sensitive acute phase reactant as $\alpha_{2}$-globulin. Further studies of mechanism of action of SK\&F D-39162 at a molecular level will shed more light on the pathogenesis of rheumatoid arthritis.

A study of a larger number of patients treated during longer periods is necessary to learn more about $\omega$ side effects and full therapeutic value of this promising new treatment for rheumatoid arthritis.

We thank Mrs. Maria Elena A. deBouza and Miss Nilvia $\overrightarrow{-}$ Giracca for their skilled technical assistance, and Dr. R. $\subsetneq$ Yabo from our Department of Statistics for the Statistical Analysis; also Drs. Lola Nudelman, A. Caballero, Robert Stote, G. Ehrlich, and Mr. M. J. DiMartino for help in $\vec{\theta}$ the selection of clinical material and/or helpful discussions के

\section{References}

Ballantyne, F. C., Fleck, A., AND Dick, W. C. (1971) Ann. rheum. Dis., 30, 265 (Albumin metabolism in rheumatoid arthritis)

CARTER, P. M. (1973) Ibid., 32, 265 (Immune complex disease)

CHODIRKER, W. B., AND TOMASI, T. B., JR. (1963) J. clin. Invest., 42, 876 (Low-molecular-weight rheumatoid factor)

Cooperating Clinics Committee of the American Rheumatism Association (1973) Arthr. and Rheum., 16, 353 (A controlled trial of gold salt therapy in rheumatoid arthritis)

Empire Rheumatism Council (1960) Ann. rheum. Dis., 19, 95 (Gold therapy in rheumatoid arthritis. Report of a multicentre controlled trial)

Finkelstein, A. E., KwoK, G., Hall, A. P., AND Bayles, T. B. (1961) New Engl. J. Med., 264, 270 (The erythrocyte

in rheumatoid arthritis. I. A method for the detection of an abnormal globulin coating)

Forestier, J. (1929) Bull. Soc. med. Hop. Paris, 53, 323 (L'aurotherapie dans les rhumatismes chroniques)

Gerber, R. C., Paulus, H. E., Bluestone, R., and Pearson, C. M. (1972) Ann. rheum. Dis., 31, 308 (Clinical response and serum gold levels in chrysotherapy)

Gordon, D. A., Koehler, B. E., Russell, M. L., Urowitz, M. B., ANd Broder, I. (1975) Ann. N. Y. Acad. Sci., 256, 338 (The clinical significance of immune complexes in rheumatoid disease)

Gotrlieb, N. L., SMith, P. M., AND SMIth, E. M. (1974) Arthr. and Rheum., 17, 171 (Pharmacodynamics of ${ }^{197} \mathrm{Au}$ and ${ }^{195} \mathrm{Au}$ labeled aurothiomalate in blood)

Kunkel, H. G., Muller-Eberhard, H. J., Fudenberg, H. H., and Tomasi, T. B. (1961) J. clin. Invest., 40, 117 (Gamma globulin complexes in rheumatoid arthritis and certain other conditions)

Lorber, A., Cohen, R. L., Chang, C. C., AND Anderson, H. E. (1968) Arthr. and Rheum., 11, 170 (Gold determination in biological fluids by atomic absorption spectrophotometry: application to chrysotherapy in rheumatoid arthritis patients)

- - Atkins, C. J., Chang, C. C., Lee, Y. B., Starrs, J., and Bovy, R. A. (1973) Ann. rheum. Dis., 32,133 (Monitoring serum gold values to improve chrysotherapy in rheumatoid arthritis)

Lowry, O. H., Rosebrough, N. J., Farr, A. L., AND Randall, R. J. (1951) J. biol. Chem., 193, 265 (Protein measurement with the folin phenol reagent)

Mancini, G., Carbonara, A. O., And Heremans, J. F. (1965) Immunochemistry, 2, 235 (Immunochemical quantitation of antigens by single radial immunodiffusion)

Mascarenhas, B. R., Granda, J. L., AND Freyberg, R. H. (1972) Arthr. and Rheum., 15, 391 (Gold metabolism in patients with rheumatoid arthritis treated with gold compounds-reinvestigated)

MuNTHE, E., AND NATVIG, J. B. (1971) Clin. exp. Immunol., 8, 249 (Characterization of IgG complexes in eluates from rheumatoid tissue) 
Pope, R. M., Mannik, M., Gilliland, B. C., ANd Teller, D. C. (1975) Arthr. and Rheum., 18, 97 (The hyperviscosity syndrome in rheumatoid arthritis due to intermediate complexes formed by self-association of IgG-rheumatoid factors)

Ropes, M. W., Bennett, G. A., CobB, S., JACox, R. F., AND JessaR, R. A. (1958) Bull. rheum. Dis., 9, 175 (Revision of diagnostic criteria for rheumatoid arthritis)

SCHROHENLOHER, R. E. (1966) J. clin. Invest., 45, 501 (Characterization of the $\gamma$-globulin complexes present in certain sera having high titers of anti- $\gamma$-globulin activity)

Sigler, J. W., Bluhm, G. B., Duncan, H., Sharp, J. T., Ensign, D. C., and McCrum, W. R. (1974) Ann. intern. Med., 80, 21 (Gold salts in the treatment of rheumatoid arthritis: a double-blind study)

Singer, J. M., AND Plotz, C. M. (1956) Amer. J. Med., 21, 888 (The latex fixation test. I. Application to the serologic diagnosis of rheumatoid arthritis)

Steinbrocker, O., Traeger, C. H., and Batterman, R. C. (1949) J. Amer. Med. Ass., 140, 659 (Therapeutic criteria in rheumatoid arthritis)

Sutton, B. M., McGusty, E., Walz, D. T., and DiMartino, M. J. (1972) J. Med. Chem., 15, 1095 (Oral gold. Antiarthritic properties of alkylphosphine gold coordination complexes)

Walz, D. T., DiMARTiNo, M. J., SuTton, B. M., AND Misher, A. (1973) 'The pharmacology of SK\&F D-39162, an orally active gold compound' in 'XIII International Congress of Rheumatology', Abst. 249. International Congress Series, No. 299. Excerpta Medica, Amsterdam

- - Chakrin, L. W., Sutton, B. M., AND Misher, A. (1976) J. Pharmacol. exp. Ther. 197, 142 (Antiarthritic properties and unique pharmacologic profile of a potential chrysotherapeutic agent: SK\&F D-39162)

Webb, J., Whaley, K., MacSween, R. N. M., Nuki, G., Carson Dick, W., and Buchanan, W. W. (1975) Ann. rheum. Dis., 34, 70 (Liver disease in rheumatoid arthritis and Sjögren's syndrome. Prospective study using biochemical and serological markers of hepatic dysfunction)

Wilkinson, P., Jeremy, R., Brooks, F. P., and Hollander, J. L. (1965) Ann. intern. Med., 63, 109 (The mechanism of hypoalbuminemia in rheumatoid arthritis) 